brazilianpoliticalsciencereview

BOOK REVIEW

\title{
Review of Transforming Brazil. A History of National Development in the Postwar Era*
}

\author{
by Maria Rita Loureiro \\ Fundação Getúlio Vargas-São Paulo, Brazil \\ (Ioris, Rafael. Transforming Brazil. A History of National Development in the
}

Postwar Era. New York: Routledge, 2014)

W hat is the need for another book on national development policy in Brazil? In the introduction, the author, a professor of Latin American History at the University of Denver, United States, seeks to undo the impression of a possible déjà vu. He indicates that the book not only includes the extensive literature published in Brazil and abroad on the subject but also an analysis of many new empirical material collected from government and private archives of many Brazilian and American research institutions. It also includes an analysis of information from newspapers and magazines and the latest literature through which he seeks to review certain interpretations of the national development policy in Brazil in the 1950s.

As a meticulous historian, the author aims to construct a broad summary of this process through an analytical focus on the Juscelino Kubitschek (JK) administration when it was at its apogee during the post-war period. Thus, the book seeks to integrate into its analysis the economic transformations linked to industrialization and the intense political and ideological debate of the period with other dimensions, which are seldom taken as a whole. Such dimensions include the expansion and diversification of the consumer society in the country, the remarkable cultural effervescence of the turbulent JK years, and the union activity 
of steel workers in São Paulo and Rio de Janeiro-one of the most mobilized segments of the working class, which increasingly became a political player in the context of the mass electoral democracy.

The author justifies the revival of the issue because of the absence of multidimensional and interdisciplinary analysis that interpret, in a broader and more nuanced manner, the complexity of the political-ideological, cultural, and labor debates of the period that are still relevant to the current Brazilian society (p. 12). Further, the rationale for the revival also depends on his assumption that intellectual creativity, cultural innovations, and the increasing politicization of workers are linked to the tragic 1964 military coup that blocked these processes (pp. 221-222).

What is the result of this great and difficult enterprise? On the one hand, it succeeds, on the flip side, it does not. This is what I propose to indicate here after a brief description of the volume.

In the first chapter, the author elucidates the emergence and consolidation of what might be referred to as a developmental consciousness in the country. This is defined by a sense of optimism due to the workability of industrialization as the path to development and the awareness of the need to create institutions and government agencies dedicated to promote it. Through the extensive literature examined, he tracks the emergence of this process during the second Vargas administration and its consolidation in the JK era. He also demonstrates how this president maintained political stability while accelerating the industrialization process, because he clearly regarded development as an instrument for reconciling the conflicting interests of developmental industrialists, conservative groups, and the demands of the working class. The following statement by JK, cited by Ioris, defines his profile as a political leader: "The social stability of our nation can only be sustained through rapid economic progress, (that way) the enemies of freedom will not thrive on the basis of poverty" (p. 38).

He refers to the convergence of the development debate in Brazil with similar processes concurrently occurring in countries in Asia and Africa during decolonization. Thus, Chapter 02 draws attention to the innovative action of Brazilian leadership on the international stage, such as Operation Pan America, defined as "the most ambitious diplomatic project of the 1950s" (p. 75). The author 
extensively describes the frustrations of diplomats and other government leaders, and of JK himself, with the low priority accorded by the US government to Brazil and Latin American countries. He further underscores the American shortsightedness regarding their demands, distinct from those of Africa and Asia, and above all, the refusal or unwillingness of American leaders to effectively contribute to the financial investment required to realize infrastructure projects in developing nations. He also emphasizes that despite its dissatisfaction, Brazil was at the helm of many multilateral initiatives and even drew reactions in its struggle for greater autonomy in international relations. In other words, Brazilian diplomacy during the JK government, while maintaining alignment with the United States in the context of the Cold War, defined a change in the pattern of relations established between the United States and Latin America after the cold war; such change, as is known, was more radical after the Cuban revolution. This information allows the author to negate the most common perception in literature that such inflection in Brazilian foreign policy only occurred during the early 1960s.

Chapter 03 reviews the implementation of a set of goals through the Development Council. In Chapter 04, we return to the political-ideological debate led by the Higher Institute of Brazilian Studies (ISEB) intellectuals-in defense of state initiatives for socially inclusive development versus the view of liberals who favored industrialization associated with private capital. The material presented in these chapters does not substantially alter the literature: while development was aimed at benefits for the larger society and although ISEB intellectual greatly influenced the debates of the period, that conception only favored particular segments when applied. The development policy was the project of the technocrats who assumed government positions and decided on the implementation of the Plano de Metas as well as well as of the JK's executive groups.

In chapter 05 , part of the material therein is seldom examined in volumes focusing on the economic, political, and ideological dimensions of national developmentalism. Resuming the examination of the position of business associations in São Paulo and Rio and their ideologues-reiterating that their developmental conceptions were restricted in scope and conservative in terms of social ambitions-Ioris further associates such formulations with material that is not usually examined in the conventional literature on development policy. He 
works with academic texts and numerous documents of the period dealing with the expansion of mass consumption in Brazil and the performance of American advertising agencies that were beginning to be established here. He emphasizes that these processes helped, coupled with the media propaganda, to build an atmosphere of enthusiasm, euphoria, and optimism that characterized the JK era. All of these, coupled with the charisma and capacity of the President, fueled the faith that economic prosperity and the promises of a better future for all would finally be acchieved. Through this thematic association-probably unprecedented in academic work, which is usually cut by more stringent disciplinary approaches-the author concludes that the development policy of the JK era, with discrepancies in the views and opinions of the business community, intellectuals, and government leaders, generated not just chaos and ideological diversity but also laid the seeds for the well-known political polarization of the subsequent period in the country's history.

Finally, Chapter 06 focuses on the increasingly autonomous mobilization of the steelworkers' unions, comprehending, through their newspapers and numerous other documents, the history and themes of the struggle of these workers during the JK administration. These themes are already found in studies on unionism and labor relations in Brazil, including the literature on land reform, which was perceived as a condition for raising productivity in the rural areas and for producing food at lower prices for urban workers (and thus fighting "rising prices", a popular battle cry of the period). However, Ioris intends, with his welldetailed analysis, to show that the dynamics of labor relations in the Brazil of the 1950s was far more complex than what the traditional historiography indicates. In addition to specific claims related to their immediate interests, analysis of the presented material shows that metallurgical workers also became involved with broader political projects in the country, articulating and promoting, through meetings, conferences, and publications, their own ideas on national development. However, the chapter ends indicating that the skepticism of workers with regard to the realization of popular demand increased as the developmental programs of the JK administration advanced, guided by other orientations. According to the author, this explains the growing political polarization of the subsequent period and consequently, the military coup. 
In fact, the intention to explain the military coup of 1964 as the necessary outcome of history arising from the diverse set of processes presented herein is problematic both methodologically and theoretically. It involves issues related to structural explanations in the form of an ex post determinism and, paradoxically, problems relating to explanations that make a case for multiple causality, which can generate indeterminacy. Furthermore, if the idea was to provide evidence and multifaceted analysis to help understand not only the zenith of national developmentalism during the JK years but also the military coup, it would have been necessary to include in this volume the analysis by Argelina Figueiredo (1993). Contrary to previous literature, she indicates that the military coup was not inevitable, rather it was the cumulative result of choices made by the political actors involved, who undermined the possibilities for reform, narrowing the field of actions and agreements that could have stemmed the progress of the right-wing movement (pp.30-31). It was also necessary to consider the pivotal role of the US government in the coup conspiracy starting before the Goulart administration, a fact that now, fifty years later, with the declassification of US government records, is thoroughly documented and can be observed in the movie "The day that lasted twenty-one years", shot by director Camilo Tavares.

From a theoretical perspective, the text also does not consider (even though the work was cited in the bibliographic references) the work of José Luiz Fiori (2003), one of the most important interpretations of the transformation of the Brazilian society over the last two centuries. Through long-term historical analysis, this author theoretically captures the structural determination of a peripheral and dependent capitalism, of a state that must assume control of the development process, and of a constitutively heterogeneous and fragmented society. Such determinants affect the action and choices of political players, which is the fundamental question of Ioris's book. One may mention, for example, the decisions of the JK administration that favored developmental programs limited only to certain social groups, in contradiction with the initial promises or even the intention to implement programs aimed at reducing poverty, by reconciling conflicting interests with conservative groups, as Ioris has underscored. These choices could be clarified in light of this theoretical debate involving structural determinations that filter and constrain the actions of political players. 
In conclusion, however, it is worth noting that although the work possesses this limitation with regard to explaining the military coup of 1964, the historical material contributed here is rich and adds value to the work. In fact, throughout the volume Rafael Ioris is able to present extensive analysis of a wide range of changes in Brazil during the JK administration. This aligned with his intention to show the important nuances and complexity of the cases examined. Furthermore, he brought aspects of Brazilian foreign policy into the national debate on developmentalism, unknown to non-specialists in the field, as is my case, as well as dimensions of the mass culture-advertising and consumptionconceptions that are little associated with the theme. He was quite successful in his intention, making his work recommendable, especially to new students of the subject.

Translated by Cabo Verde

\section{References}

FIGUEIREDO, Argelina (1993), Democracia e Reformas? Alternativas democráticas à crise política. Rio de Janeiro: Paz e Terra.

FIORI, José Luis (2003), o vôo da coruja. Para reler o desenvolvimentismo brasileiro. Rio de Janeiro: Editora Record. 